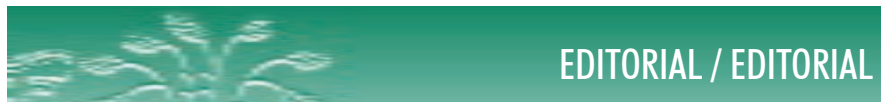

DOI 10.12957/demetra.2014.10827

\title{
Suporte financeiro e ética em publicações científicas
}

Financial support and ethics in scientific publications

Um conjunto importante de publicações recentes tem dirigido seu foco para questões relativas à ciência no Brasil. Programas de pós-graduação, pesquisadores e periódicos científicos têm sido objeto de inúmeras análises em face da necessidade de avaliação de atividades, de agentes e de regras dos jogos que têm lugar nesse campo da vida. Interesses de toda ordem atravessam o campo científico, com destaque para aqueles associados aos financiadores de atividades voltadas para a disseminação dos resultados das pesquisas científicas.

Entendemos que periódicos científicos, como outros espaços de ação no âmbito da ciência, devem ser absolutamente transparentes quanto aos interesses que os marcam, o que inclui relações com seus patrocinadores. Nesse sentido, consideramos fundamental explicitar nossas fontes de financiamento. Além disso, ressaltamos que é imperioso deixar sempre muito claros os procedimentos que adotamos e os princípios que nos amparam quando buscamos apoio para nossa sobrevivência financeira.

No Brasil, parcela substantiva da pesquisa é desenvolvida com recursos públicos. É nosso ponto de vista que os conhecimentos assim gerados devam retornar à sociedade por meio de acesso aberto aos textos completos, sem custos ou barreiras para o autor ou para o leitor.

As fontes de financiamento que nos sustentam devem manter conosco identidade quanto aos referenciais éticos que nos orientam. A independência e a autonomia da revista no que concerne ao que é publicado são pilares que nos sustentam. Nesse sentido, é com profundo orgulho e vislumbrando um horizonte sólido para nosso projeto editorial que anunciamos a obtenção de apoio financeiro da Fundação Carlos Chagas Filho de Amparo à Pesquisa do Estado do Rio de Janeiro (FAPERJ) à DEMETRA: Alimentação, Nutrição Ẻ Saúde, por ocasião do Edital no 44/2013 de Apoio à Publicação de Periódicos Científicos e Tecnológicos Institucionais. 
Além do importante recurso financeiro que permitirá ampliação de nossas atividades, contamos agora com o reconhecimento de nossos esforços por parte de uma instituição das mais respeitáveis no Brasil. São capitais financeiros e simbólicos que nos conferem reconhecimento pelo árduo trabalho, legitimando a qualidade dos resultados alcançados.

Neste ano de 2014, todo o nosso Corpo Editorial está absolutamente empenhado e envidaremos muitos outros esforços em busca de novas indexações internacionais. O campo científico da Alimentação e Nutrição no Brasil precisa de mais periódicos de alto nível acadêmico, ético e social.

Leitores, autores e avaliadores de artigos: contamos com sua intensa participação nesse processo! Enviem-nos seus bons trabalhos. Nós os avaliaremos com atenção, cuidado e agilidade.

Sigamos juntos construindo nossa DEMETRA: Alimentação, Nutrição \& Saúde!

Shirley Donizete Prado

Editora 